\title{
Food selection by Plumatella geimermassardi Wood and Okamura, 2004 (Phylactolaemata, Bryozoa)
}

\author{
Chiara Todini, Antonia Concetta Elia*, Roberta Selvaggi, Melissa Scoparo and \\ Maria Illuminata Taticchi \\ Department of Chemistry, Biology and Biotechnology, University of Perugia, 06123 Perugia, Italy
}

\begin{abstract}
Bryozoans are sessile filter feeding organisms able to play an important role in the cycling of organic matter in freshwater ecosystems. However, the quality and quantity of food particles ingested by bryozoans are still not well-known. Therefore, an experimental design was performed in order to investigate the clearance rate (CR), food selection and efficiency of assimilation by the freshwater bryozoan species Plumatella geimermassardi. P. geimermassardi was collected from the Colfiorito Marsh (Umbrian Natural Park, Italy), during summer. A higher grazing rate of suspended and dissolved solids was evidenced in the colonies collected in June, July, than in August. Food selection and assimilation of phytoplankton were determined. The algal species ingested as diet food item and those excreted with the faecal pellets were taxonomically identified. The results provide new information on $\mathrm{CR}$ and food selection by $P$. geimermassardi and enhance knowledge on its biology. Insights on feeding preferences by bryozoan species can provide valid information about their feasible distribution and abundance.
\end{abstract}

Keywords: Assimilation / clearance rate / dissolved and suspended solids / freshwater bryozoans / phytoplankton

Résumé - Sélection des aliments par Plumatella geimermassardi Wood et Okamura, 2004 (Phylactolaemata, Bryozoaire). Les bryozoaires sont des organismes filtreurs sessiles capables de jouer un rôle important dans le cycle de la matière organique dans les écosystèmes d'eau douce. Cependant, la qualité et la quantité de particules alimentaires ingérées par les bryozoaires ne sont pas encore connues. Par conséquent, un plan expérimental a été réalisé afin d'étudier le taux de clairance, la sélection des aliments et l'efficacité de l'assimilation par l'espèce de bryozoaire d'eau douce Plumatella geimermassardi. P. geimermassardi a été récoltée dans le marais de Colfiorito (Parc naturel ombrien, Italie), pendant l'été. Le taux de broutage des solides en suspension et dissous a été plus élevé dans les colonies collectées en juin, juillet, qu'en août. La sélection des aliments et l'assimilation du phytoplancton ont été déterminées. Les espèces d'algues ingérées comme aliments et celles excrétées avec les granules fécaux ont été identifiées taxonomiquement. Les résultats fournissent de nouvelles informations sur le taux de clairance et la sélection des aliments par $P$. geimermassardi et améliorent les connaissances sur sa biologie. Les observations sur les préférences alimentaires des espèces de bryozoaires peuvent fournir des informations valides sur leur répartition probable et leur abondance.

Mots-clés : Assimilation / taux de clairance / solides dissous et en suspension / bryozoaires d'eau douce / phytoplancton

\section{Introduction}

Concentration of dissolved organic matter (DOM) in natural waterbodies is related with geochemistry, seasons and water category. In aquatic environments mass of DOM is higher than that of organisms (Thomas, 1997). In boreal surface waters DOM consists mostly of humic substances (refractory organic matter), while the remnant part is mainly composed by

\footnotetext{
*Corresponding author: antonia.elia@unipg.it
}

carbohydrates, amino acids, low molecular weight organic and fatty acids (labile fraction). The inorganic fraction of dissolved solids is mineral salts. Suspended organic material includes phytoplankton and biotic debris, while inorganic suspended solids are represented by clay, sand, silt, volcanic ash, silica, aluminum oxides, iron, calcium carbonate and particulate matter of anthropogenic origin (Thomas, 1997).

Filter feeders include a wide variety of organisms able to perform a fundamental ecological role in aquatic ecosystems. Filter feeders increase the transparency and water quality by 
removing suspended particles. They form an important link between dissolved and suspended solids and the higher levels of the food chain, contributing to nutrient cycling and regulation of the metabolism of freshwater ecosystems (Ostroumov, 2005). Any loss of filter feeders caused by the introduction of environmental contaminants, allochthonous species or by removal of suitable habitats, seriously threatens the functioning and stability of freshwater environments (Ostroumov, 2002a, b, 2003a, b). Consequently, several studies investigated clearance rate (CR) of sponges, cladocera, rotifers, bivalves and polychaetes (Gauld, 1951; Monakov, 1998).

Bryozoans are benthic suspension-feeding invertebrates thriving in freshwater and marine habitats (Okamura and Partridge, 1999; Taticchi et al., 2005; Wood and Okamura, 2005). They are sessile colonial animals living attached on a variety of submerged substrates. A colony of freshwater Bryozoa has genetically identical zooids characterized by a ciliated tentacular crown called lophophore surrounding the mouth. With its ciliated tentacles, the lophophore creates a water flow carrying particles, mainly phytoplankton, to its mouth (Taticchi, 1989; Okamura and Doolan, 1993; Shunatova and Ostrovsky, 2001). Examination of bryozoan feeding habit is important in order to improve knowledge on interspecific and intraspecific competition, and the ecology of mentioned sessile suspension-feeders (Best and Thorpe, 1983). Moreover, freshwater Bryozoa are considered as bioindicators of environmental disturbance and pollution (Bushnell, 1974; Henry et al., 1989; Wöss, 1994; Elia et al., 2001, 2006, 2007).

Limited information is available on the CRs and diets of bryozoan species living in their specific environment. Published data deal mainly with marine and freshwater bryozoans fed experimentally in laboratory (Bullivant, 1968; Best and Thorpe, 1983; Okamura and Doolan, 1993; Lisbjerg and Petersen, 2000, 2001). The few studies carried out on freshwater bryozoans not fed experimentally include Taticchi (1989) dealing with Plumatella repens Linnaeus, 1758, Plumatella casmiana Oka, 1908, Fredericella sultana Blumenbach, 1779 and Paludicella articulata (Ehrenberg, 1831) from Lake Trasimeno, and Kaminski (1991a, b) studying Plumatella fungosa Pallas, 1768. Several experiments carried out on $P$. fungosa, using bacterial suspensions, showed the ability of this species to feed on bacterioplankton, thus confirming its role in water cleansing (Richelle et al., 1994). Capture of particles by bryozoans depends on food characteristics (e.g. type, size and concentration), colony features (e.g. shape, size, number of living zooids and lophophore size) and environmental conditions (e.g. temperature, water velocity and salinity) (Okamura, 1987; Riisgård and Manriquez, 1997; Eckman and Okamura, 1998; Okamura and Partridge, 1999; Lisbjerg and Petersen, 2001; Pratt, 2008). However, CR of certain freshwater bryozoan species may be related only with food concentration (Vohmann et al., 2009).

Freshwater bryozoans play an important role collecting suspended particles and transferring some of the food particles they ingest to the bottom of their environment as faecal pellets. They also may compete with the zooplankton when food resources are limited (Taticchi et al., 2009).

Plumatella geimermassardi Wood and Okamura (2004) is a freshwater bryozoan species. Wood and Okamura (2004) described this species after having reviewed the major Phylactolaemate bryozoan collections from south Scandinavian,
British Isles and North continental Europe, complemented by intensive field surveys during 2000 and 2001. In Italy $P$. geimermassardi is limited to North Italy and Umbria (Central Italy) in Lake Piediluco (Taticchi et al., 2005) and in the Colfiorito Marsh (Rubini et al., 2011).

The latter is one of the most interesting and important wetland in Italy and in Umbria valued for its biodiversity (Orsomando et al., 2004). Since 1973 the marsh has been included in "The Ramsar List of Wetlands of International Importance and, since 1995 as a Site of Community Importance (SCI) and a special protected areas (SPA) according to BIOITALY (IT5210034 and IT5210072).

The aim of this study was to investigate the CR, food selection and efficiency of assimilation by $P$. geimermassardi in the Colfiorito Marsh during summer months when bryozoan colonies occur.

\section{Materials and methods}

\subsection{Sampling}

Colfiorito Marsh is located in Central Italy $\left(43^{\circ} 00^{\prime} 58^{\prime \prime} \mathrm{N}\right.$; $\left.12^{\circ} 52^{\prime} 54^{\prime \prime} \mathrm{E}\right)$ and falls within the central part of the UmbrianMarches ridge. The marsh covers 157 ha and is located as a tectonic depression in a strongly karstified bedrock. The marsh is permanent, but restricted because affected by level fluctuations throughout the year $(40-160 \mathrm{~cm})$. The outflow is mainly the Molinaccio sinkhole. Colfiorito is also a peculiar environment influenced by the presence of abundant floating vegetation (Mentha acquatica Linnaeus, Myriophyillum spicatum Linnaeus, Myriophyillum verticillatum Linnaeus, Nymphaea alba Linnaeus). A single sampling station was selected on the north side of the Colfiorito Marsh, at Molinaccio, where the mean depth was $1.5 \mathrm{~m}$. A variety of submerged substrates were inspected for sampling bryozoan colonies, namely hydrophytes and helophytes, floating trunks, stones and artificial substrates of different nature (e.g. plastics, glass). Colonies were gently removed using tweezers without compromising their integrity. Three bryozoan species were found in the marsh: Plumatella fruticosa (Allman, 1844), $P$. repens and $P$. geimermassardi, and the latter was abundant from June to August 2007. Water samples were collected using a Ruttner bottle $(500 \mathrm{ml})$ in order to measure the total solids (TS), total dissolved solids (TDS), total suspended solids (TSS), and phytoplankton. Water samples were filtered in situ (100 $\mu \mathrm{m}$-mesh) in order to remove any zooplanktonic filter feeders which could affect the results, and then stored in plastic bottles (PE). For phytoplankton determination water samples were placed in $50 \mathrm{ml}$ pots and fixed in situ with Lugol solution (Magazzù, 1978). Bryozoans and water samples were transported to the laboratory in coolers equipped with a Peltier device at $4{ }^{\circ} \mathrm{C}$. Chemical-physical parameters (temperature, conductivity, $\mathrm{pH}$ and dissolved oxygen) (Tab. 1) were measured in situ. Conductivity (E.C.) was determined using portable HI8733 conductivity meter (range: $0-1999 \mu \mathrm{S} \mathrm{cm}^{-1}$, precision: $1 \%$, resolution $1 \mu \mathrm{S} \mathrm{cm}^{-1}$ ) while $\mathrm{pH}$ and temperature using the portable HI98150 pHmeter (range: $\mathrm{pH}-4.00$ to 19.99 , precision $\pm 0.02 \mathrm{pH}$, resolution $0.01 \mathrm{pH}$ ) and dissolved oxygen using Simplair F Syland Scientific portable sensor (range: 0-20.0 ppm dissolved $\mathrm{O}_{2}$, precision: $1 \%$ ). 
Table 1. Chemical-physical parameters of Colfiorito Marsh water.

\begin{tabular}{lccll}
\hline Sampling months & $\mathrm{T}\left({ }^{\circ} \mathrm{C}\right)$ & $\mathrm{pH}$ & Conductivity $\left(\mu \mathrm{Sm}^{-1}\right)$ & $\mathrm{O}_{2}\left(\mathrm{mg} \mathrm{L}^{-1}\right)$ \\
\hline June & $23.5 \pm 1.6$ & $9.3 \pm 0.9$ & $403.3 \pm 31.5$ & $7.6 \pm 0.6 \mathrm{a}$ \\
July & $25.5 \pm 0.7$ & $8.3 \pm 0.4$ & $409.0 \pm 11.3$ & $6.5 \pm 0.7 \mathrm{ab}$ \\
August & $25.0 \pm 1.4$ & $8.3 \pm 0.1$ & $413.5 \pm 5.0$ & $4.5 \pm 0.7 \mathrm{~b}$ \\
\hline
\end{tabular}

Mean \pm SD. Number of replicates for each sampling month (2). The letters (a, b) indicate statistically significant differences between sampling months $(p<0.05)$.

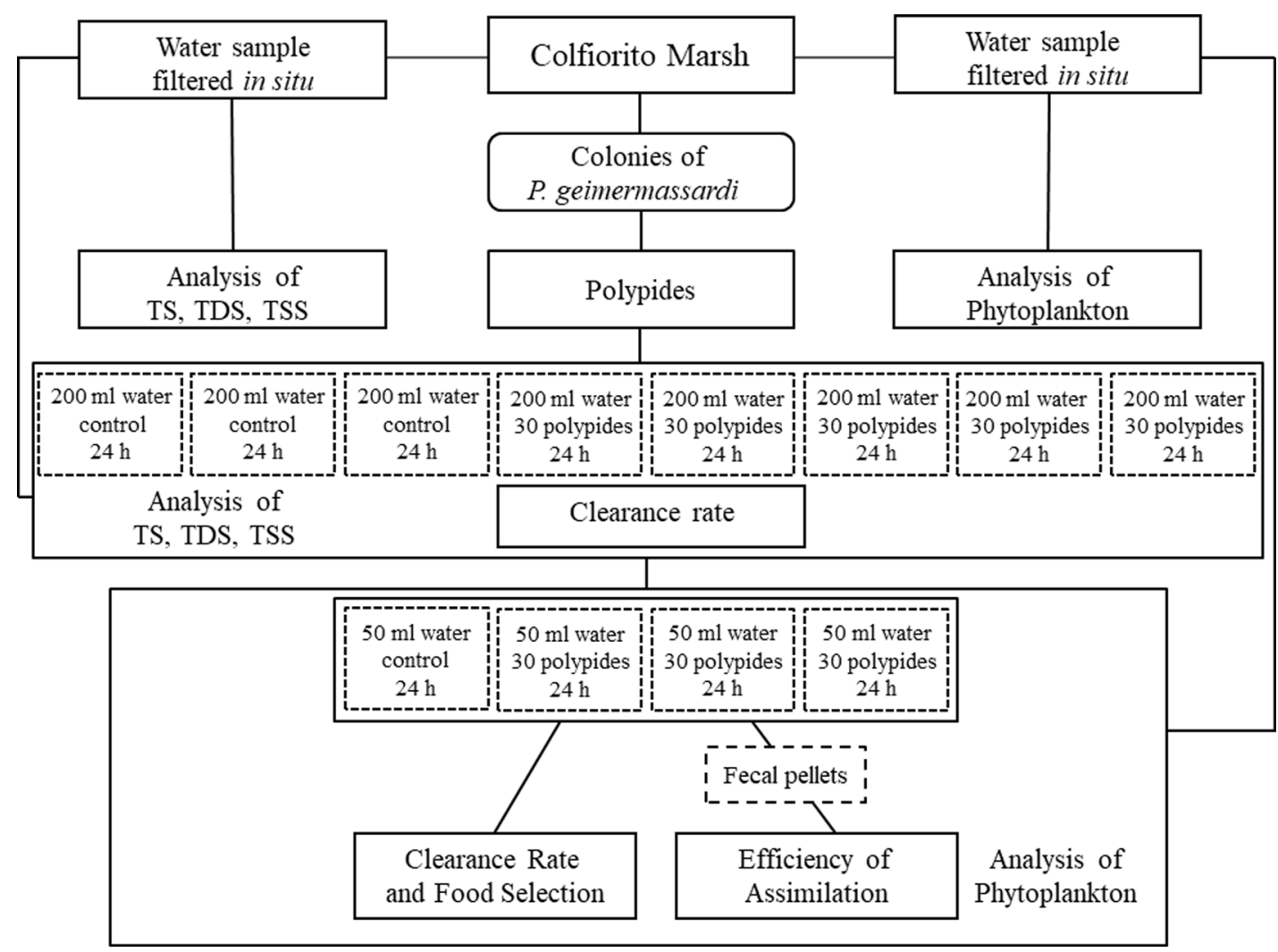

Fig. 1. Experimental design to set up the clearance rates, degree of food selection and efficiency of assimilation of freshwater bryozoan Plumatella geimermassardi from the Colfiorito Marsh.

\subsection{Experimental design}

Among the three bryozoan species found in Colfiorito Marsh, P. geimermassardi was the most abundant. Hence, the experiments of filtration and food assimilation were performed using this species in a static system using the same water collected from sampling station. In laboratory, the colonies were cleaned from associated organisms and debris, placed in Petri glass dishes with SMB III, a buffer solution at $\mathrm{pH} 6.8$ (Miyake et al., 2003). They were then acclimatized in a cooled incubator under dark conditions at the same temperature recorded at sampling station. Every $12 \mathrm{~h}$ was checked the dynamic ciliary movement of colonies and observing an evident reduction of ciliary activity from $36 \mathrm{~h}$ onwards, the incubation period was fixed for $24 \mathrm{~h}$. Therefore, an experimental procedure was applied in order to optimize incubation conditions of bryozoan colonies and the analysis methods (Fig. 1).

\subsection{Clearance rates of solids}

After acclimatization (during which the polypides released their gut content through faecal pellets) colonies were divided into 5 fragments of 30 polypides each. The experiment started once the vitality of all polypides and the expansion of their lophophores were assessed. Each fragment was placed in a Petri dish (5 replicates) with $200 \mathrm{ml}$ of filtered marsh water and then incubated for $24 \mathrm{~h}$ under the same acclimation conditions (Fig. 1). Further 3 Petri dishes each containing $200 \mathrm{ml}$ of filtered marsh water were incubated at the same conditions for control (Fig. 1). At the end of the experiment, specimens were removed and observed under a stereomicroscope (Zeiss; $10 \times$ ocular, $4 \times$ objectives) to verify the health condition of polypides, and in case record the number of deceased individuals. Then colony portions were preserved in a ethylic alcohol solution (EtOH 70\%/glycerol/water: 4/3/3 vol) for further analyses. 
At the beginning and at the end of the experiment concentration of TS, TDS and TSS in experimental and control pots were measured by the weight method using $200 \mathrm{ml}$ of water samples (APAT-IRSA-CNR, 2003; APHA, AWWA, WEF, 1998). TS were detected evaporating to dryness water samples in a weighed dish at $105^{\circ} \mathrm{C}$, and consequently the increase in dish weight represented the TS. TSS and TDS were obtained filtering the sample through a weighed standard glassfiber filter with a $0.45 \mu \mathrm{m}$ pore diameter. The residues retained on the filter and the filtrate, collected in a weighed dish, were dried to a constant weight at $105^{\circ} \mathrm{C}$. The increase in filter weight and in dish weight represented the TSS and the TDS, respectively.

The CR was calculated according to the following formula (Gauld, 1951):

$$
\mathrm{CR}=\frac{\left[V\left(\ln C_{0}-\ln C_{1}\right)-\left(\ln C \iota_{0}-\ln C \iota_{1}\right)\right]}{N t},
$$

where $V$ is the water volume, $t$ the experimental period, $C_{0}$ and $C_{1}$ the initial and final concentration of TS in the experimental pots, $C^{\prime}{ }_{0}$ and $C^{\prime}{ }_{1}$ the initial and final concentration of TS in the control pots and $N$ is the number of polypides.

CRs were determined comparing concentration of solids before (pre-exposure) and after (post-exposure) polypides were collocated in the Petri dishes for $24 \mathrm{~h}$. During this time frame specimens were fed and water cleared. The values were corrected for passive losses of suspended solids by sedimentation and by suspended organic matter degradation using control treatments containing only marsh water (Vohmann et al., 2009). Loss rates $\left(R, \mathrm{~h}^{-1}\right)$ were calculated by assuming exponential changes.

$$
R=\frac{\left(\ln C_{0}-\ln C_{1}\right)}{t} .
$$

The differences between the initial and final concentration of TS in the pots containing active polypides $\left(R_{a}\right)$ and control pots $\left(R_{c}\right)$ were considered as grazing rate $\left(R_{g r}\right)$.

$$
R_{g r}=\left(R_{a}\right)-\left(R_{c}\right) .
$$

The grazing rate multiplied for the volume of Petri dish and divided by the number of polypides yielded for the CR ( $\mu$ lind $\mathrm{in}^{-1} \mathrm{~h}^{-1}$ ) (Vohmann et al., 2009).

\subsection{Clearance rate, food selection and assimilation of phytoplankton species}

The CR of phytoplankton was calculated following the same procedure described above. In order to evaluate the degree of selection of phytoplankton species 30 polypides were placed in Petri dishes (3 replicates and one control) containing $50 \mathrm{ml}$ of marsh water and kept in an incubator for $24 \mathrm{~h}$ under dark conditions at the temperature recorded at the sampling station (Fig. 1). Gut content $\left(r_{i}\right)$ was assessed as the difference between algal biomass in control pots $\left(\ln C_{0}\right)$ and in those containing active polypides for $24 \mathrm{~h}\left(\ln C_{1}\right)$, since it was not possible to carefully distinguish the ingested food from the faecal pellets in the gut.
Electivity or degree of selection was quantified by the ratio $E$ according to the formula of Ivlev's (1961) electivity index:

$$
E=\frac{r_{1}-p_{1}}{r_{1}+p_{1}}
$$

where $E=$ measure of electivity; $r_{1}=$ relative biomass of algal species present in the gut content; $p_{1}=$ relative biomass of the same algal species present in the environment.

This index may range from -1 to +1 ; the negative values indicate avoidance or less efficient food selection, zero denotes random selection and positive values indicate active selection.

The efficiency of assimilation was evaluated by analyzing the content of 10 faecal pellets of each experimental dish that were analyzed as a single sample. Faecal pellets just emitted by zooids were collected using micropipettes and crushed between a slide and coverslip for microscopic examination. From the faecal pellets content it was possible to evaluate the quantity and quality of the ingested algae of the Colfiorito Marsh. The efficiency of assimilation was quantified by the ratio $A$ according to the formula of Ivlev's (1961) electivity index slightly modified:

$$
A=\frac{f_{1}-r_{1}}{f_{1}+r_{1}},
$$

where $A=$ efficiency of assimilation; $f_{1}=$ relative biomass of undigested algal species in faecal pellets; $r_{1}=$ relative biomass of algal species present in the gut content.

This index may range from -1 (positive assimilation) to +1 (negative assimilation).

The classification and counting of phytoplankton species (Utermöhl, 1958) was carried out using Olympus inverted system microscope for filtered marsh water, experimental dishes and faecal pellets. Counts were done at $400 \times$ magnification and at least 400 phytoplankton units were identified to the lowest feasible taxonomic level (Havens et al., 2009). Cell volumes were calculated by approximating shapes to regular geometric solids, and population biovolumes $\left(\mu \mathrm{m}^{3} \mathrm{~L}^{-1}\right)$ were determined as density $\times$ cell volume for each species.

\subsection{Statistical analysis}

Statistical analysis was performed using GraphPad Prism version 5.0. Grazing rate, clearance rate, gut content and faecal pellets were quantified by computing the log-transformation (ln) of data. Homogeneity of variance was checked with Levene test. One-way ANOVA followed by Bonferroni's multiple comparisons tests and $T$-test were used to discriminate differences among groups at each time point. Main effects of sampling months and exposures were determined by 2-way ANOVA with Bonferroni's multiple comparisons test. Significance was assessed at $\alpha$ level of 0.05 .

\section{Results}

Chemical-physical parameters of marsh water showed values almost similar between the three sampling months, except for oxygen content which was lower in August 
Table 2. Concentration of total solids (TS), total dissolved solids (TDS), total suspended solids (TSS) before (pre-exposure) and $24 \mathrm{~h}$ after collocation (post-exposure) of active polypides, grazing rate $\left(R_{g r}\right)$ and clearance rate $(\mathrm{CR})$.

\begin{tabular}{lccccc}
\hline \multicolumn{2}{c}{ Sampling months } & Pre-exposure $\left(\mathrm{mg} \mathrm{L}^{-1}\right)$ & Post-exposure $\left(\mathrm{mg} \mathrm{L}^{-1}\right)$ & $R_{g r}\left(\mu \mathrm{g} \mathrm{L}^{-1} \mathrm{~h}^{-1}\right)$ & $\mathrm{CR}^{2}\left(\mu 1 \mathrm{ind} \mathrm{C}^{-1} \mathrm{~h}^{-1}\right)$ \\
\hline June & TS & $229.4 \pm 0.2 \mathrm{~b}$ & $132.9 \pm 4.7 \mathrm{~b}^{*}$ & $66.1 \pm 9.4 \mathrm{a}$ & $440.3 \pm 62.6 \mathrm{a}$ \\
July & TS & $229.9 \pm 1.7 \mathrm{~b}$ & $129.9 \pm 2.4 \mathrm{~b}^{*}$ & $56.1 \pm 2.2 \mathrm{a}$ & $374.0 \pm 14.7 \mathrm{a}$ \\
August & TS & $298.6 \pm 0.9 \mathrm{a}$ & $226.1 \pm 6.9 \mathrm{a}^{*}$ & $24.8 \pm 3.8 \mathrm{~b}$ & $163.3 \pm 25.4 \mathrm{~b}$ \\
June & TDS & $201.7 \pm 0.2 \mathrm{~b}$ & $123.5 \pm 3.3 \mathrm{~b}^{*}$ & $20.4 \pm 1.1 \mathrm{a}$ & $136.3 \pm 7.4 \mathrm{a}$ \\
July & TDS & $199.1 \pm 1.8 \mathrm{~b}$ & $116.1 \pm 2.2 \mathrm{c}{ }^{*}$ & $22.5 \pm 0.7 \mathrm{a}$ & $149.9 \pm 4.6 \mathrm{a}$ \\
August & TDS & $250.2 \pm 1.0 \mathrm{a}$ & $191.0 \pm 5.9 \mathrm{a}{ }^{*}$ & $11.2 \pm 1.2 \mathrm{~b}$ & $75.0 \pm 7.9 \mathrm{~b}$ \\
June & TSS & $27.7 \pm 0.2 \mathrm{~b}$ & $9.4 \pm 2.0 \mathrm{c}^{*}$ & $45.6 \pm 8.7 \mathrm{a}$ & $304.0 \pm 57.8 \mathrm{a}$ \\
July & TSS & $30.8 \pm 0.5 \mathrm{~b}$ & $13.8 \pm 0.6 \mathrm{~b}^{*}$ & $33.6 \pm 2.0 \mathrm{a}$ & $224.1 \pm 13.0 \mathrm{a}$ \\
August & TSS & $48.4 \pm 0.4 \mathrm{a}$ & $35.1 \pm 2.5 \mathrm{a}^{*}$ & $13.6 \pm 3.3 \mathrm{~b}$ & $90.4 \pm 22.3 \mathrm{~b}$ \\
\hline
\end{tabular}

Total solids are the sum of inorganic and organic dissolved and suspended solids. Polypides (ind). Mean \pm SD. Number of replicates for each sampling month (5). The letters $(\mathrm{a}, \mathrm{b}, \mathrm{c})$ indicate statistically significant differences between sampling months $(p<0.05)$.

* indicates statistically significant differences before and after collocation of polypides.

$\left(4.5 \pm 0.7 \mathrm{mg} \mathrm{L}^{-1}\right)$ than in June $\left(7.6 \pm 0.6 \mathrm{mg} \mathrm{L}^{-1}\right)(p<0.05)$ (Tab. 1).

In Colfiorito Marsh, TDS concentration measured in control waters represented $80-90 \%$ of the TS. When comparing the solid concentrations at the two endpoints (at beginning and at the end of experiment), low values $(p<0.05)$ of TS, TDS and TSS were recorded in the pots containing active polypides. In June and July, the TDS concentration in the experimental pots $\left(123.5 \pm 3.3\right.$ and $116.1 \pm 2.2 \mathrm{mg} \mathrm{L}^{-1}$, respectively) was about $40 \%$ lower than in control ones $\left(201.7 \pm 0.2\right.$ and $199.1 \pm 1.8 \mathrm{mg} \mathrm{L}^{-1}$, respectively). In the same months, TSS concentration in pots containing active polypides $\left(9.4 \pm 2.0\right.$ and $13.8 \pm 0.6 \mathrm{mg} \mathrm{L}^{-1}$, June and July, respectively) was about $60 \%$ lower than in controls $(27.7 \pm 0.2$ and $30.8 \pm 0.5 \mathrm{mg} \mathrm{L}^{-1}$, June and July, respectively). In August, concentration of TDS $\left(191.0 \pm 5.9 \mathrm{mg} \mathrm{L}^{-1}\right)$ and TSS $\left(35.1 \pm 2.5 \mathrm{mg} \mathrm{L}^{-1}\right)$ in the experimental pots was about $25 \%$ lower than in control ones $\left(250.2 \pm 1.0\right.$ and $48.4 \pm 0.4 \mathrm{mg} \mathrm{L}^{-1}$, respectively) (Tab. 2).

In June and July, grazing rate $\left(R_{g r}\right)$ and clearance rate $(\mathrm{CR})$ were generally higher for suspended solids than for the dissolved ones. In August, both values of $R_{g r}$ and CRs were almost similar $(p<0.05)$. Values of $R_{g r}$ for TDS (about $40 \%$ ) and TSS (about 70\%) in August were lower than, in June (Tab. 2). Similarly to the $R_{g r}$ lower values of CRs were found in August for TS $\left(163.3 \pm 25.4 \mu \mathrm{lind} \mathrm{i}^{-1} \mathrm{~h}^{-1}\right)$, TDS $(75.0 \pm 7.9 \mu \mathrm{l}$ ind $\left.^{-1} \mathrm{~h}^{-1}\right)$ and TSS $\left(90.4 \pm 22.3 \mu l\right.$ ind $\left.^{-1} \mathrm{~h}^{-1}\right)$, when compared with June $\left(440.3 \pm 62.6,136.3 \pm 7.4\right.$ and $304.0 \pm 57.8 \mu$ ind $^{-1}$ $\mathrm{h}^{-1}$, respectively) and July $(374.0 \pm 14.7,149.9 \pm 4.6$ and $224.1 \pm 13.0 \mu \mathrm{lind}^{-1} \mathrm{~h}^{-1}$, respectively) $(p<0.05)$ (Tab. 2).

Phytoplankton of Colfiorito Marsh (Tab. 3) was characterized by the presence of Ultraplankton composed of 6 algal classes and 23 species. However, qualitative and quantitative composition of phytoplankton changed throughout the three sampling months. A total of 17 species were recorded in June, 21 in July and 17 in August. Highest biomass density of phytoplankton in control marsh water was noted in June for Ultraplankton $\left(600.0 \pm 147.3 \mu \mathrm{gL}^{-1}\right)$, while Cyanophyceae were represented by only one species Raphidiopsis curvata F. E. Fritsch and M.F. Rich $\left(29.3 \pm 3.8 \mu \mathrm{g} \mathrm{L}^{-1}\right)$, in July for Chlorophyceae (11 species; $3392.0 \pm 254.0 \mu \mathrm{g} \mathrm{L}^{-1}$ ) and Coniugatophyceae with the only species Staurastrum tetracerum
Ralfs ex Ralfs $\left(172.7 \pm 17.0 \mu \mathrm{gL}^{-1}\right)$, and in August for Bacillariophyceae (6 species; $\left.914.7 \pm 93.0 \mu \mathrm{g} \mathrm{L}^{-1}\right)$. As shown in Table 3, biomass density of Ultraplankton, Chlorophyceae, Bacillariophyceae and Euglenophyceae was two-threefold higher at the beginning of the experiment than after bryozoan filtered water for $24 \mathrm{~h}$. In fact, collocating $P$. geimermassardi in marsh water revealed a statically significant reduction $(70 \%$; $p<0.05$ ) of biomass density of Ultraplankton in June, total Chlorophyceae (35\%) in July, total Bacillariophyceae (50 $70 \%$ ), and total Euglenophyceae (40-50\%) through the three sampling months.

The highest values $(p<0.05)$ of grazing rates $\left(\mathrm{ng} \mathrm{L}^{-1} \mathrm{~h}^{-1}\right)$ and CRs $\left(\mu 1\right.$ ind $\left.^{-1} \mathrm{~h}^{-1}\right)$ were recorded for Amphora ovalis (Kützing) Kützing $\left(86.4 \pm 4.2 \mathrm{ng} \mathrm{L}^{-1} \mathrm{~h}^{-1} ; 143.9 \pm 7.0 \mu \mathrm{lind}^{-1}\right.$ $\mathrm{h}^{-1}$ ) and Fragilaria acus (Kützing) Lange-Bertalot $\left(31.3 \pm 8.7 \mathrm{ng} \mathrm{L}^{-1} \mathrm{~h}^{-1} ; 52.2 \pm 14.5 \mu \mathrm{ind}^{-1} \mathrm{~h}^{-1}\right)$ in June, Tetraedron minimum (A. Braun) Hansgirg $\left(65.3 \pm 7.3 \mathrm{ng} \mathrm{L}^{-1} \mathrm{~h}^{-1}\right.$; $\left.108.9 \pm 12.1 \mu \mathrm{lnd}^{-1} \mathrm{~h}^{-1}\right)$ in July, and Scenedesmus ellipsoideus Chodat $\left(58.3 \pm 12.6 \mathrm{ng} \mathrm{L}^{-1} \mathrm{~h}^{-1} ; 97.2 \pm 21.0 \mu \mathrm{ind}^{-1} \mathrm{~h}^{-1}\right)$ in August (Tab. 4).

Percentages of biomass density of phytoplankton in gut content and total faecal pellets indicating the undigested algal cells, degree of selection $(E)$ and efficiency of assimilation $(A)$ are shown in Table 5. The positive $E$-values for phytoplankton ranged from 0.1 to 0.7 . Low positive values of degree of selection were found for Ultraplankton in June $(E ; 0.1)$ and August $(E$; 0.2 ). Number of algal species actively selected from environment was higher in July (12) than in June (8) and August (8). Among all algal species, the highest positive $E$-values, from 0.4 onwards, were registered for Ankistrodesmus falcatus (Corda) Ralfs (E; 0.6), Crucigenia quadrata Morren (E; 0.7), Kirchneriella obesa (West) West and G. S. West $(E ; 0.5)$ and A. ovalis $(E ; 0.4)$ in June; A. falcatus, K. obesa, Scenedesmus quadricauda (Turpin) Brébisson, Gomphonema acuminatum Ehrenberg $(E ; 0.4)$, and $T$. minimum $(E ; 0.5)$ in July; $S$. ellipsoideus $(E ; 0.5)$, A. ovalis $(E ; 0.4)$ and $G$. acuminatum $(E$; $0.7)$ in August. Highest positive $E$-values were thus registered for 6 green algae and 2 diatoms. Ultraplankton and the algal species, such as $C$. quadrata $(A ;-1), K$. obesa $(A ;-1), S$. quadricauda $(A ;-1)$, T. minimum $(A ;-1)$, and $G$. acuminatum $(A ;-1)$, which were not found in the faecal pellets, but likely ingested and positively selected, were the most assimilated items 
C. Todini et al.: Knowl. Manag. Aquat. Ecosyst. 2018, 419, 26

Table 3. Biomass density of phytoplankton before (pre-exposure) and $24 \mathrm{~h}$ after collocation (post-exposure) of active polypides.

\begin{tabular}{|c|c|c|c|c|c|c|}
\hline$\mu \mathrm{g} \mathrm{L}^{-1}$ & $\begin{array}{c}\text { June } \\
\text { pre-exposure }\end{array}$ & $\begin{array}{c}\text { June } \\
\text { post-exposure }\end{array}$ & $\begin{array}{c}\text { July } \\
\text { pre-exposure }\end{array}$ & $\begin{array}{c}\text { July } \\
\text { post-exposure }\end{array}$ & $\begin{array}{c}\text { August } \\
\text { pre-exposure }\end{array}$ & $\begin{array}{c}\text { August } \\
\text { post-exposure }\end{array}$ \\
\hline Ultraplankton & $600.0 \pm 147.3^{*} \mathrm{a}$ & $180.3 \pm 60.9^{*}$ & $284.3 \pm 98.1 b$ & $150.0 \pm 29.0$ & $200.0 \pm 36.1 \mathrm{~b}$ & $50.0 \pm 4.6$ \\
\hline $\begin{array}{l}\text { Raphidiopsis curvata } \\
\text { F.E. Fritsch and M.F. Rich } \\
\text { Total Cyanophyceae }\end{array}$ & $29.3 \pm 3.8^{*} \mathrm{a}$ & $14.7 \pm 3.9^{*}$ & $14.3 \pm 3.8 \mathrm{~b}$ & $7.3 \pm 3.5$ & $21.1 \pm 3.4^{*} \mathrm{ab}$ & $9.7 \pm 2.5^{*}$ \\
\hline Ankistrodesmus falcatus (Corda) Ralfs & $4.3 \pm 0.4^{*}$ & $1.7 \pm 0.4^{*}$ & $3.3 \pm 1.3$ & $2.1 \pm 0.6$ & - & - \\
\hline $\begin{array}{l}\text { Ankistrodesmus spiralis (W.B. Turner) } \\
\text { Lemmermann }\end{array}$ & - & - & $4.8 \pm 0.9$ & $4.0 \pm 0.5$ & - & - \\
\hline Coelastrum microporum Nägeli & - & - & - & - & $4.8 \pm 0.7$ & $3.5 \pm 0.9$ \\
\hline Crucigenia quadrata Morren & $4.5 \pm 1.2^{*}$ & $1.1 \pm 0.2^{*}$ & - & - & $3.4 \pm 0.8$ & $3.0 \pm 1.0$ \\
\hline $\begin{array}{l}\text { Kirchneriella obesa (West) } \\
\text { West \& G. S. West }\end{array}$ & $12.1 \pm 2.5^{*}$ & $3.0 \pm 1.0^{*}$ & $13.7 \pm 4.4^{*}$ & $6.9 \pm 1.0^{*}$ & - & - \\
\hline Pediastrum duplex Meyen & $1140.0 \pm 119.8$ & $1107.2 \pm 111.0$ & $1354.0 \pm 209.5$ & $1328.7 \pm 188.4$ & - & - \\
\hline $\begin{array}{l}\text { Scenedesmus ecornis (Ehrenberg) } \\
\text { Chodat }\end{array}$ & $64.1 \pm 9.7^{*} \mathrm{~b}$ & $33.9 \pm 6.7^{*}$ & $90.6 \pm 5.9^{*} \mathrm{a}$ & $45.6 \pm 7.1^{*}$ & - & - \\
\hline Scenedesmus ellipsoideus Chodat & $16.2 \pm 2.0^{*} \mathrm{a}$ & $8.0 \pm 1.1^{*}$ & $10.0 \pm 1.0 \mathrm{~b}$ & $6.7 \pm 1.8$ & $16.2 \pm 2.1^{*} \mathrm{a}$ & $4.0 \pm 1.0^{*}$ \\
\hline $\begin{array}{l}\text { Scenedesmus quadricauda (Turpin } \\
\text { Brébisson }\end{array}$ & $7.0 \pm 0.4 b$ & $6.4 \pm 0.7$ & $14.1 \pm 1.8^{*} \mathrm{a}$ & $7.0 \pm 1.3^{*}$ & $19.4 \pm 4.1^{*} \mathrm{a}$ & $12.3 \pm 1.6^{*}$ \\
\hline Selenastrum bibraianum Reinsch & $609.3 \pm 135.2 \mathrm{a}$ & $304.0 \pm 50.5$ & $1599.0 \pm 259.4^{*} \mathrm{~b}$ & $558.8 \pm 39.7^{*}$ & $914.0 \pm 136.5^{*} \mathrm{a}$ & $457.0 \pm 91.5^{*}$ \\
\hline $\begin{array}{l}n \text { tetras (Ehrenberg) } \\
\text { ald }\end{array}$ & - & - & $190.4 \pm 21.9$ & $186.0 \pm 22.0$ & - & - \\
\hline $\begin{array}{l}\text { Tetraedron minimum (A.Braun) } \\
\text { Hansgirg }\end{array}$ & $74.7 \pm 8.2$ & $71.3 \pm 7.1$ & $89.2 \pm 24.9^{*}$ & $18.6 \pm 5.5^{*}$ & $76.6 \pm 7.6$ & $71.0 \pm 9.8$ \\
\hline $\begin{array}{l}\text { Tetradesmus obliquus (Turpin) } \\
\text { M. J. Wynne }\end{array}$ & $28.3 \pm 1.9 b$ & $14.2 \pm 1.1$ & $46.5 \pm 11.8^{*} \mathrm{a}$ & $24.3 \pm 3.9^{*}$ & - & - \\
\hline Total Chlorophyceae & $1960.6 \pm 177.8 b$ & $1550.8 \pm 191.2$ & $3392.0 \pm 254.0^{*} \mathrm{a}$ & $2190.3 \pm 209.1^{*}$ & $1035.5 \pm 132.4 \mathrm{c}$ & $550.9 \pm 85.7$ \\
\hline $\begin{array}{l}\text { Staurastrum tetracerum Ralfs ex Ralfs } \\
\text { Total Coniugatophyceae }\end{array}$ & $114.0 \pm 18.3 \mathrm{~b}$ & $112.7 \pm 19.1$ & $172.7 \pm 17.0 \mathrm{a}$ & $171.0 \pm 18.4$ & $116.0 \pm 14.7 b$ & $114.0 \pm 15.1$ \\
\hline $\begin{array}{l}\text { Dinobrion sp. } \\
\text { Total Chrysophyceae }\end{array}$ & $93.5 \pm 16.3 b$ & $90.1 \pm 17.9$ & - & - & $248.7 \pm 37.0 \mathrm{a}$ & $245.4 \pm 37.7$ \\
\hline Amphora ovalis (Kützing) Kützing & $240.4 \pm 50.9^{*}$ & $30.0 \pm 4.6^{*}$ & $180.3 \pm 17.5^{*}$ & $75.1 \pm 5.8^{*}$ & $300.5 \pm 44.9^{*}$ & $45.3 \pm 5.3^{*}$ \\
\hline $\begin{array}{l}\text { Fragilaria acus (Kützing) } \\
\text { Lange-Bertalot }\end{array}$ & $29.3 \pm 5.7^{*} \mathrm{a}$ & $13.7 \pm 0.4^{*}$ & $14.8 \pm 1.5 b$ & $14.6 \pm 1.3$ & $21.9 \pm 8.7 \mathrm{ab}$ & $14.7 \pm 2.4$ \\
\hline a acuminatum Ehre & - & - & $8.5 \pm 2.0^{*}$ & $4.3 \pm 1.0^{*}$ & $2.8 \pm 0.8$ & - \\
\hline constrictum Ehrenberg & - & - & & & $89.1 \pm 13.1^{*}$ & $44.5 \pm 4.5^{*}$ \\
\hline Navicula cryptocephala Kützing & - & - & $12.5 \pm 1.8$ & $12.4 \pm 1.8$ & - & - \\
\hline $\begin{array}{l}\text { Rhoichosphenia abbreviata } \\
\text { (C.Agardh) Lange-Bertalot }\end{array}$ & $237.5 \pm 39.9 b$ & $94.7 \pm 9.0$ & $296.9 \pm 63.8 \mathrm{ab}$ & $148.4 \pm 51.6$ & $475.1 \pm 122.9 \mathrm{a}$ & $267.2 \pm 107.9$ \\
\hline Ulnaria ulna (Nitzsch) Compère & - & - & - & - & $25.3 \pm 1$ & $23.5 \pm 1$ \\
\hline Total Bacillariophyceae & $507.2 \pm 95.8^{*} \mathrm{~b}$ & $138.3 \pm 13.4^{*}$ & $631.8 \pm 60.7^{*} \mathrm{~b}$ & $314.2 \pm 42.7^{*}$ & $914.7 \pm 93.0^{*} \mathrm{a}$ & $395.2 \pm 99.0^{*}$ \\
\hline Euglena $s p$ & $1357.0 \pm 179.4^{*} \mathrm{~b}$ & $603.3 \pm 99.0^{*}$ & $1131.5 \pm 305.3 \mathrm{a}$ & $664.5 \pm 99.5^{*}$ & $1508 \pm 318.0^{*} \mathrm{a}$ & $452.6 \pm 108.0^{*}$ \\
\hline $\begin{array}{l}\text { Trachelomonas volvocina (Ehrenberg) } \\
\text { Ehrenberg }\end{array}$ & - & - & $204.7 \pm 47.4$ & $136.5 \pm 29.5$ & $272.9 \pm 92.1$ & $169.6 \pm 22.8$ \\
\hline Total Euglenophyceae & $1357.0 \pm 179.4^{*}$ & $603.3 \pm 99.0^{*}$ & $1336.2 \pm 306.3^{*}$ & $801.0 \pm 116.0^{*}$ & $1780.9 \pm 310.3^{*}$ & $622.2 \pm 98.2^{*}$ \\
\hline
\end{tabular}

Mean \pm SD. Number of replicates for each sampling month (3). The letters (a, b, c) indicate statistically significant differences between each pre-exposure.

${ }^{*}$ indicates statistically significant differences before and after collocation of polypides for each sampling month $(p<0.05)$. Not determined $(-)$.

by $P$. geimermassardi. Algal species, like $R$. curvata $(A ; 0.2-$ June, 0.1-August), Scenedesmus ecornis (Ehrenberg) Chodat ( $A$; 0.5-June, 0.4-July), S. ellipsoideus (A; 0.2-June, 0.6-July), Selenastrum bibraianum Reinsch (A; 0.6-June, 0.2-July, 0.5August), Tetradesmus obliquus (Turpin) M. J. Wynne (A; 0.3June, 0.5-July), A. ovalis (A; 0.1-June, 0.3-July), Gomphonema constrictum ( $A$; 0.4-July, 0.5-August), and Ulnaria ulna
(Nitzsch) Compère ( $A$; 0.9-August), showing positive $A$-values, were the less assimilated items by $P$. geimermassardi.

\section{Discussion and conclusions}

P. geimermassardi was abundantly found in the Colfiorito Marsh from June to August. Only few colonies were present in 
Table 4. Grazing rate $\left(R_{g r}\right)$ and clearance rate $(\mathrm{CR})$ of $P$. geimermassardi of phytoplankton of the Colfiorito Marsh.

\begin{tabular}{|c|c|c|c|c|c|c|}
\hline & Jun- $R_{g r}$ & $\mathrm{Jul}-R_{g r}$ & Aug- $R_{g r}$ & Jun-CR & Jul-CR & Aug-CR \\
\hline Ultraplankton & $51.0 \pm 5.0$ & $25.4 \pm 11.8$ & $57.4 \pm 8.7$ & $85.0 \pm 8.4 \mathrm{a}$ & $42.4 \pm 19.6 b$ & $95.7 \pm 14.4 \mathrm{a}$ \\
\hline R. curvata & $29.4 \pm 7.7$ & $30.2 \pm 10.7$ & $33.1 \pm 13.0$ & $49.0 \pm 12.8$ & $50.4 \pm 17.8$ & $55.2 \pm 21.7$ \\
\hline A. falcatus & $40.5 \pm 12.6$ & $16.5 \pm 10.0$ & - & $67.4 \pm 20.9$ & $27.5 \pm 16.7$ & - \\
\hline A. spiralis & - & $7.1 \pm 6.0$ & - & - & $11.8 \pm 10.0$ & - \\
\hline C. microporum & - & - & $13.4 \pm 7.2$ & - & - & $22.3 \pm 12.0$ \\
\hline C. quadrata & $57.1 \pm 16.7 \mathrm{a}$ & - & $5.8 \pm 4.8 b$ & $95.2 \pm 27.8 \mathrm{a}$ & - & $9.7 \pm 8.0 \mathrm{~b}$ \\
\hline K. obesa & $58.6 \pm 18.8$ & $27.3 \pm 20.3$ & - & $97.7 \pm 31.3$ & $45.5 \pm 33.9$ & - \\
\hline P. duplex & $1.2 \pm 0.2$ & $0.7 \pm 0.7$ & - & $2.0 \pm 0.4$ & $1.2 \pm 1.2$ & - \\
\hline S. ecornis & $26.8 \pm 11.4$ & $28.9 \pm 4.8$ & - & $44.6 \pm 19.1$ & $48.2 \pm 7.9$ & - \\
\hline S. ellipsoideus & $29.2 \pm 9.2 \mathrm{ab}$ & $17.8 \pm 13.5 b$ & $58.3 \pm 12.6 \mathrm{a}$ & $48.6 \pm 15.4 \mathrm{ab}$ & $29.7 \pm 22.5 b$ & $97.2 \pm 21.0 \mathrm{a}$ \\
\hline S. quadricauda & $4.2 \pm 2.4$ & $29.1 \pm 12.9$ & $18.4 \pm 14.4$ & $7.0 \pm 3.9$ & $48.4 \pm 21.5$ & $30.7 \pm 24.0$ \\
\hline S. bibraianum & $28.6 \pm 2.9$ & $43.5 \pm 9.5$ & $29.2 \pm 6.6$ & $47.7 \pm 4.9$ & $72.5 \pm 15.9$ & $48.6 \pm 10.9$ \\
\hline S. tetras & - & $1.0 \pm 0.4$ & - & - & $1.6 \pm 0.6$ & - \\
\hline T. minimum & $1.9 \pm 0.6 b$ & $65.3 \pm 7.3 \mathrm{a}$ & $3.9 \pm 2.2 b$ & $3.1 \pm 1.0 \mathrm{~b}$ & $108.9 \pm 12.1 \mathrm{a}$ & $6.4 \pm 3.7 b$ \\
\hline T. obliquus & $28.9 \pm 2.7$ & $26.6 \pm 17.2$ & - & $48.2 \pm 4.5$ & $44.4 \pm 28.7$ & - \\
\hline S. tetracerum & $0.8 \pm 0.7$ & $0.4 \pm 0.4$ & $0.7 \pm 0.4$ & $1.3 \pm 1.2$ & $0.7 \pm 0.7$ & $1.2 \pm 0.7$ \\
\hline Dinobrion $s p$. & $2.5 \pm 0.6 \mathrm{a}$ & - & $0.6 \pm 0.3 b$ & $4.1 \pm 1.0 \mathrm{a}$ & - & $0.9 \pm 0.5 b$ \\
\hline A. ovalis & $86.4 \pm 4.2 \mathrm{a}$ & $36.4 \pm 1.1 \mathrm{c}$ & $78.7 \pm 1.5 b$ & $143.9 \pm 7.0 \mathrm{a}$ & $60.7 \pm 1.9 \mathrm{c}$ & $131.2 \pm 2.6 \mathrm{~b}$ \\
\hline F. acus & $31.3 \pm 8.7 \mathrm{a}$ & $0.6 \pm 0.4 \mathrm{c}$ & $14.6 \pm 12.7 b$ & $52.2 \pm 14.5 \mathrm{a}$ & $1.1 \pm 0.7 \mathrm{c}$ & $24.4 \pm 21.2 b$ \\
\hline G. acuminatum & - & $28.7 \pm 5.2$ & $42.2 \pm 11.5$ & - & $47.9 \pm 8.6$ & $70.3 \pm 19.2$ \\
\hline G. constrictum & - & $28.7 \pm 9.9$ & $28.7 \pm 9.5$ & - & $47.8 \pm 16.5$ & $47.8 \pm 15.8$ \\
\hline N. cryptocephala & - & $0.3 \pm 0.13$ & - & - & $0.6 \pm 0.1$ & - \\
\hline R. abbreviata & $38.1 \pm 3.1$ & $30.3 \pm 25.1$ & $25.5 \pm 6.9$ & $63.4 \pm 5.1$ & $50.5 \pm 41.8$ & $42.5 \pm 11.4$ \\
\hline U. ulna & - & - & $3.1 \pm 0.5$ & - & - & $5.2 \pm 0.9$ \\
\hline Euglena sp. & $33.9 \pm 7.0$ & $21.5 \pm 16.8$ & $50.3 \pm 13.3$ & $56.5 \pm 11.7$ & $35.9 \pm 28.0$ & $83.9 \pm 22.1$ \\
\hline T. volvocina & - & $16.8 \pm 0.9$ & $18.5 \pm 13.0$ & - & $28.0 \pm 1.5$ & $30.8 \pm 21.6$ \\
\hline
\end{tabular}

$R_{g r}\left(\right.$ ng L $\left.{ }^{-1} \mathrm{~h}^{-1}\right), \mathrm{CR}\left(\mu l\right.$ ind $\left.^{-1} \mathrm{~h}^{-1}\right)$. Mean \pm SD. Polypides (ind). Number of replicates for each sampling month (3). The letters (a, b, c) indicate statistically significant differences between the sampling months for Ultraplankton and each algal species $(p<0.05)$. Not determined $(-)$.

May, September and October. P. geimermassardi may limit the number of colonies during spring and autumn, and only resting stages can persist in Colfiorito during the winter. Water temperature is an important ecological factor that may affect both CRs of filter feeders and growth rates of their planktonic prey (Vohmann et al., 2009). Feeding ability of freshwater bryozoan species (Vohmann et al., 2009) and other biological processes (Elia et al., 2001, 2006, 2007) may be more active at the beginning than at the end of their growth cycle. Most colonies of $P$. geimermassardi were found under the surface of M. acquatica, M. spicatum, M. verticillum and $N$. alba. Abundance of $N$. alba, which leaves develop near the water surface hindered light penetration and hence impaired photosynthesis in the underlying strata, may explain the low oxygen concentration in marsh water recorded in August. Colonies adhere to the substratum with encrusting branching tubes covering large areas while zooecial tubes are cylindrical and transparent with U-shaped lophophore. Number of tentacles ranged from 41 to 58, which is higher than the 30-40 reported for P. geimermassardi by Wood and Okamura (2004). The tentacles number may change for a species and even between zooids within the same colony. Variation in tentacles number, as well as their size, may be related to their environment and food availability (Jebram 1973). Unlike marine bryozoans whose lophophores are bell shaped and include 8-34 tentacles (Winston, 1977), Phylactolaemata possess U-shaped lophophores with numerous ciliated tentacles (Lacourt, 1968). A positive relationship between the strength of the feeding currents and the size of the lophophore was recorded for marine bryozoans (Best and Thorpe, 1986). Okamura and Doolan (1993) suggested that Phylactolaemates characterized by larger lophophores and by closer ciliary proximity should produce relatively more powerful feeding currents, allowing them to feed from lotic and also from lentic environments. These lophophores may be significant for feeding, where flow lack limits resource renewal.

It is renowned that bryozoans may be able to include in their diet algae, bacteria, detritus, small protozoans, and organic substances dissolved in water (Bushnell, 1974). Like other filter-feeders food ingestion for $P$. geimermassardi may not depend on particles availability or speed of water flow, but on the ability of the pharynx to swallow particles, and from the filtration capacity of the species.

Once a filter-feeder is positioned in a closed pot containing suspension of particles, the CR can be assessed measuring the rate in concentration change of suspended particles (Bullivant, 1968). Furthermore, rates at which suspension feeders may clear water suspensions and ingest food are important parameters for an ecological analysis of aquatic ecosystems (Bullivant, 1968).

Published data are available on filtering activity of several and different benthic filter-feeders (Ostroumov, 2005). CRs have been expressed in terms of volume of cleared water, rather than the amount of food particles ingested in a given 
C. Todini et al.: Knowl. Manag. Aquat. Ecosyst. 2018, 419, 26

Table 5. Relative biomass density of phytoplankton in gut content (GC) and faecal pellets (FP), degree of selection $(E)$ and efficiency of assimilation $(A)$ of $P$. geimermassardi.

\begin{tabular}{|c|c|c|c|c|c|c|c|c|c|c|c|c|c|c|c|}
\hline Phytoplankton & Jun-GC & & In-FP & & un- $E$ & & an- $A$ & Jul-GC & Jul-FP & Jul- $E$ & Jul- $A$ & Aug-GC & Aug-FP & Aug- $E$ & Aug- $A$ \\
\hline Ultraplankton & \multicolumn{3}{|c|}{$\begin{array}{ll}9.4 & 0 \\
{[7.7 ; 10.5]} & \end{array}$} & \multicolumn{2}{|c|}{$\begin{array}{l}0.1 \\
{[0.1 ; 0.1]}\end{array}$} & \multicolumn{2}{|l|}{-1} & $\begin{array}{l}5.2 \\
{[3.8 ; 7.9]}\end{array}$ & [- & \multicolumn{2}{|c|}{$\begin{array}{l}-0.2 \quad-1 \\
{[-0.2 ;-0.2]}\end{array}$} & $\begin{array}{l}11.9 \\
{[9.8 ; 13.5]}\end{array}$ & - & $\begin{array}{l}0.2 \\
{[0.2 ; 0.3]}\end{array}$ & -1 \\
\hline R. curvata & 5.4 & \multicolumn{2}{|c|}{$\begin{array}{l}7.5 \\
{[6.2 ; 8.6]}\end{array}$} & \multicolumn{2}{|c|}{0.2} & $\begin{array}{l}0.2 \\
{[0 ; 0}\end{array}$ & & 6.2 & $\begin{array}{l}4.1 \\
{[2.7 ; 5.5]}\end{array}$ & $\begin{array}{l}0.3 \\
{[0.1 ; 0.5]}\end{array}$ & -0.4 & $\begin{array}{ll}6.9 & 7 \\
{[3.8 ; 8.9]} & {[}\end{array}$ & $\begin{array}{l}7.4 \\
{[6.3 ; 8.6]}\end{array}$ & $\begin{array}{l}0.3 \\
{[0.3 ; 0.4]}\end{array}$ & $\begin{array}{l}0.1 \\
{[-0.1 ; 0.4]}\end{array}$ \\
\hline A. falcatus & $\begin{array}{l}7.3 \\
{[5.4 ; 8.8]}\end{array}$ & \multicolumn{2}{|c|}{$\begin{array}{l}3.5 \\
{[2.8 ; 4.2]}\end{array}$} & \multicolumn{2}{|c|}{$\begin{array}{l}0.6 \\
{[0.5 ; 0.6]}\end{array}$} & \multicolumn{2}{|c|}{$\begin{array}{l}-0.3 \\
{[-0.4 ;-0.3]}\end{array}$} & $\begin{array}{l}3.4 \\
{[3.8 ; 7.7]}\end{array}$ & $\begin{array}{l}0.9 \\
{[0.7 ; 1.3]}\end{array}$ & $\begin{array}{l}0.4 \\
{[0.2 ; 0.6]}\end{array}$ & \multirow{2}{*}{$\begin{array}{l}-0.5 \\
{[-0.8 ;-0.3]} \\
-1\end{array}$} & - & - & - & - \\
\hline A. spiralis & - & - & & - & & - & & $\begin{array}{l}1.4 \\
{[0.7 ; 2.8]}\end{array}$ & - & $\begin{array}{l}-0.4 \\
{[-0.4 ;-0.3]}\end{array}$ & & - & - & - & - \\
\hline C. microporum - & - & - & & - & & - & & - & - & $\begin{array}{ll}- & -\end{array}$ & - & $\begin{array}{l}2.8 \\
{[1.5 ; 4.4]}\end{array}$ & $\begin{array}{l}0 . \\
{[0}\end{array}$ & $\begin{array}{l}0.2 \\
{[0.1 ; 0.3]}\end{array}$ & -1 \\
\hline C. quadrata & $\begin{array}{l}10.3 \\
{[7.4 ; 13.2]}\end{array}$ & - & & $\begin{array}{l}0.7 \\
{[0.7}\end{array}$ & $0.7]$ & -1 & & - & - & - & - & $\begin{array}{l}1.2 \\
{[0.2 ; 2.2]}\end{array}$ & - & $\begin{array}{l}-0.5 \\
{[-0.8 ;-0.2]}\end{array}$ & -1 \\
\hline K. obesa & $\begin{array}{l}10.4 \\
{[8.6 ; 13.2]}\end{array}$ & - & & $\begin{array}{l}0.5 \\
{[0.5}\end{array}$ & $0.6]$ & -1 & & $\begin{array}{l}5.6 \\
{[1.2 ; 9.3]}\end{array}$ & - & $\begin{array}{l}0.4 \\
{[0.4 ; 0.5]}\end{array}$ & -1 & - & - & - & - \\
\hline P. duplex & $\begin{array}{l}0.2 \\
{[0.2 ; 0.3]}\end{array}$ & - & & $\begin{array}{l}-1 \\
{[-1}\end{array}$ & $-0.9]$ & -1 & & $\begin{array}{l}0.2 \\
{[0.1 ; 0.3]}\end{array}$ & [ & $\begin{array}{l}-1 \\
{[-1 ;-0.9]}\end{array}$ & -1 & - & - & - & - \\
\hline S. ecornis & $\begin{array}{l}4.8 \\
{[2.8 ; 5.9]}\end{array}$ & $\begin{array}{l}15.9 \\
{[14 .}\end{array}$ & $9 ; 16.8]$ & $\begin{array}{l}-0 . \\
{[-0}\end{array}$ & $3 ; 0]$ & $\begin{array}{l}0.5 \\
{[0.5}\end{array}$ & 0.7] & $\begin{array}{l}6.0 \\
{[4.8 ; 7.0]}\end{array}$ & $\begin{array}{ll}13.6 & 0 \\
{[13.1 ; 13.9]} & {[}\end{array}$ & $\begin{array}{l}0.1 \\
{[0.1 ; 0.2]}\end{array}$ & $\begin{array}{l}0.4 \\
{[0.3 ; 0.5]}\end{array}$ & - & - & - & - \\
\hline S. ellipsoideus & $\begin{array}{l}5.2 \\
{[3.8 ; 6.2]}\end{array}$ & $\begin{array}{l}8.6 \\
{[7.2}\end{array}$ & ; 9.8] & $\begin{array}{l}0.2 \\
{[0.2}\end{array}$ & $0.3]$ & $\begin{array}{l}0.2 \\
{[0.1}\end{array}$ & $0.4]$ & $\begin{array}{l}3.6 \\
{[1.4 ; 6.6]}\end{array}$ & $\begin{array}{l}7.0 \\
{[5.7 ; 8.4]}\end{array}$ & $\begin{array}{l}0.3 \\
{[0.1 ; 0.4]}\end{array}$ & $\begin{array}{l}0.6 \\
{[0.4 ; 0.7]}\end{array}$ & $\begin{array}{ll}12.1 & 7 \\
{[9.2 ; 14.0]} & \end{array}$ & $\begin{array}{l}7.0 \\
{[4.6 ; 9.3]}\end{array}$ & $\begin{array}{l}0.5 \\
{[0.4 ; 0.6]}\end{array}$ & $\begin{array}{l}-0.3 \\
{[-0.5 ;-0.1]}\end{array}$ \\
\hline S. quadricauda 0 & $\begin{array}{l}0.8 \\
{[0.3 ; 1.1]}\end{array}$ & - & & $\begin{array}{l}-0 . \\
{[-0}\end{array}$ & $8 ;-0.4]$ & -1 & & $\begin{array}{l}6.0 \\
{[3.0 ; 7.5]}\end{array}$ & - & $\begin{array}{l}0.4 \\
{[0.4 ; 0.4]}\end{array}$ & -1 & $\begin{array}{l}5.5 \\
{[4.4 ; 6.5]}\end{array}$ & $\begin{array}{l}0 . \\
{[0}\end{array}$ & $\begin{array}{l}0.1 \\
{[0 ; 0.2]}\end{array}$ & -1 \\
\hline S. bibraianum & $\begin{array}{l}5.3 \\
{[4.5 ; 6.2]}\end{array}$ & $\begin{array}{l}17.4 \\
{[16 .}\end{array}$ & $2 ; 18.8]$ & $\begin{array}{l}-0.2 \\
{[-0 .}\end{array}$ & $3 ;-0.2]$ & $\begin{array}{l}0.6 \\
{[0.5 ;}\end{array}$ & $0.6]$ & $\begin{array}{l}9.0 \\
{[6.9 ; 11.2]}\end{array}$ & $\begin{array}{ll}14.7 & 0 \\
{[14.1 ; 15.2]} & \end{array}$ & $\begin{array}{l}0.1 \\
{[0.1 ; 0.2]}\end{array}$ & $\begin{array}{l}0.2 \\
{[0.1 ; 0.4]}\end{array}$ & $\begin{array}{l}6.0 \\
{[4.5 ; 6.9]}\end{array}$ & $\begin{array}{l}18.3 \\
{[16.8 ; 20.0]}\end{array}$ & $\begin{array}{l}-0.2 \\
{[-0.3 ;-0.1]}\end{array}$ & $\begin{array}{l}0.5 \\
{[0.4 ; 0.6]}\end{array}$ \\
\hline S. tetras & - & - & & - & & - & & {$[0.1 ; 0.3]$} & - & $\begin{array}{l}-0.9 \\
{[-0.9 ;-0.9]}\end{array}$ & -1 & - & - & - & - \\
\hline T. minimum & $\begin{array}{l}0.3 \\
{[0.2 ; 0.4]}\end{array}$ & - & & $\begin{array}{l}-0 . \\
{[-0}\end{array}$ & $9 ;-0.9]$ & -1 & & $\begin{array}{l}13.5 \\
{[12.0 ; 15.3]}\end{array}$ & $\begin{array}{l}0 \\
{[0}\end{array}$ & $\begin{array}{l}0.5 \\
{[0.4 ; 0.5]}\end{array}$ & -1 & $\begin{array}{l}0.8 \\
{[0.5 ; 1.3]}\end{array}$ & - & $\begin{array}{l}-0.7 \\
{[-0.8 ;-0.6]}\end{array}$ & -1 \\
\hline Phytoplankton & Jun-GC & & Jun-F & & Jun- & & Jun- $A$ & Jul-GC & Jul-FP & Jul- $E$ & Jul- $A$ & Aug-GC & Aug-FP & Aug- $E$ & Aug- $A$ \\
\hline T. obliquus & $\begin{array}{l}5.3 \\
{[5.0 ; 5.5]}\end{array}$ & & $\begin{array}{l}9.3 \\
{[8.6 ; 10 .}\end{array}$ & & $\begin{array}{l}0.1 \\
{[0 ; 0.1]}\end{array}$ & & $\begin{array}{l}0.3 \\
{[0.2 ; 0.3]}\end{array}$ & $\begin{array}{l}5.5 \\
{[2.9 ; 9.7]}\end{array}$ & $\begin{array}{l}10.0 \\
{[9.7 ; 10.3]}\end{array}$ & $\begin{array}{l}0.2 \\
{[0 ; 0.4]}\end{array}$ & $\begin{array}{l}0.5 \\
{[0.4 ; 0.6]}\end{array}$ & - & - & - & - \\
\hline S. tetracerum & $\begin{array}{l}0.1 \\
{[0 ; 0.2]}\end{array}$ & & - & & $\begin{array}{l}-1 \\
{[-1 ;-0}\end{array}$ & & -1 & $\begin{array}{l}0.1 \\
{[0 ; 0.2]}\end{array}$ & - & $\begin{array}{l}-1 \\
{[-1 ;-0.9]}\end{array}$ & -1 & $\begin{array}{l}0.2 \\
{[0.1 ; 0.3]}\end{array}$ & - & $\begin{array}{l}-1 \\
{[-0.9 ;-1]}\end{array}$ & -1 \\
\hline Dinobrion $s p$ & $\begin{array}{l}0.5 \\
{[0.3 ; 0.6]}\end{array}$ & & - & & $\begin{array}{l}-0.9 \\
{[-1 ;-0}\end{array}$ & & -1 & - & - & - & - & $\begin{array}{l}0.1 \\
{[0.1 ; 0.2]}\end{array}$ & - & -1 & -1 \\
\hline A. ovalis & $\begin{array}{l}15.8 \\
{[14.4 ; 18}\end{array}$ & & $\begin{array}{l}18.7 \\
{[17.3 ; 20}\end{array}$ & & $\begin{array}{l}0.4 \\
{[0.4 ; 0.4}\end{array}$ & & $\begin{array}{l}0.1 \\
{[0 ; 0.1]}\end{array}$ & $\begin{array}{l}7.5 \\
{[7.1 ; 7.9]}\end{array}$ & $\begin{array}{l}15.4 \\
{[14.6 ; 16.0]}\end{array}$ & $\begin{array}{l}0.2 \\
{[0.2 ; 0.2]}\end{array}$ & $\begin{array}{l}0.3 \\
{[0.3 ; 0.4]}\end{array}$ & $\begin{array}{l}16.3 \\
{[16.1 ; 16.5]}\end{array}$ & $\begin{array}{l}16.9 \\
{[15.7 ; 18.2]}\end{array}$ & $\begin{array}{l}0.4 \\
{[0.4 ; 0.4]}\end{array}$ & $\begin{array}{l}0 \\
{[0 ; 0.1]}\end{array}$ \\
\hline F. acus & $\begin{array}{l}5.8 \\
{[4.1 ; 8.3]}\end{array}$ & & - & & $\begin{array}{l}0.2 \\
{[0.1 ; 0.3}\end{array}$ & & -1 & $\begin{array}{l}0.1 \\
{[0 ; 0.2]}\end{array}$ & - & $\begin{array}{l}-0.9 \\
{[-1 ;-0.9]}\end{array}$ & -1 & $\begin{array}{l}1.7 \\
{[0.5 ; 2.8]}\end{array}$ & - & $\begin{array}{l}-0.5 \\
{[-0.7 ;-0.2}\end{array}$ & -1 \\
\hline G. acuminatum & - & & - & & - & & - & $\begin{array}{l}6.0 \\
{[5.1 ; 7.2]}\end{array}$ & - & $\begin{array}{l}0.4 \\
{[0.3 ; 0.5]}\end{array}$ & -1 & $\begin{array}{l}8.7 \\
{[7.1 ; 11.4]}\end{array}$ & - & $\begin{array}{l}0.7 \\
{[0.7 ; 0.7]}\end{array}$ & -1 \\
\hline G. constrictum & - & & - & & - & & - & $\begin{array}{l}5.9 \\
{[3.6 ; 7.2]}\end{array}$ & $\begin{array}{l}14.8 \\
{[14.3 ; 15.4]}\end{array}$ & $\begin{array}{l}0.1 \\
{[0.1 ; 0.2]}\end{array}$ & $\begin{array}{l}0.4 \\
{[0.3 ; 0.6]}\end{array}$ & $\begin{array}{l}6.0 \\
{[3.6 ; 7.1]}\end{array}$ & $\begin{array}{l}15.4 \\
{[14.8 ; 16.2]}\end{array}$ & $\begin{array}{l}0.1 \\
{[0.1 ; 0.1]}\end{array}$ & $\begin{array}{l}0.5 \\
{[0.4 ; 0.6]}\end{array}$ \\
\hline N. cryptocephala & - & & - & & - & & - & $\begin{array}{l}0.1 \\
{[0.1 ; 0.1]}\end{array}$ & - & $\begin{array}{l}-0.9 \\
{[-1 ;-0.9]}\end{array}$ & -1 & - & - & - & - \\
\hline R. abbreviata & $\begin{array}{l}7.0 \\
{[6.2 ; 8.5]}\end{array}$ & & - & & $\begin{array}{l}0 \\
{[-0.1 ; 0}\end{array}$ & & -1 & $\begin{array}{l}6.3 \\
{[2.5 ; 12.4]}\end{array}$ & - & $\begin{array}{l}-0.3 \\
{[-0.4 ;-0.2]}\end{array}$ & -1 & $\begin{array}{l}5.3 \\
{[3.9 ; 6.7]}\end{array}$ & - & $\begin{array}{l}-0.2 \\
{[-0.4 ;-0.1}\end{array}$ & 1] ${ }^{-1}$ \\
\hline U. ulna & - & & - & & - & & - & - & - & - & - & $\begin{array}{l}0.7 \\
{[0.5 ; 0.8]}\end{array}$ & $\begin{array}{l}20.6 \\
{[19.1 ; 22.8]}\end{array}$ & $\begin{array}{l}-0.7 \\
{[-0.8 ;-0.7}\end{array}$ & $\begin{array}{l}0.9 \\
\text { 7] }[0.9 ; 0.9]\end{array}$ \\
\hline Euglena sp. & $\begin{array}{l}6.1 \\
{[5.4 ; 6.6]}\end{array}$ & & $\begin{array}{l}20.3 \\
{[18.8 ; 22}\end{array}$ & & $\begin{array}{l}-0.2 \\
{[-0.3 ;}\end{array}$ & & $\begin{array}{l}0.5 \\
{[0.5 ; 0.6]}\end{array}$ & $\begin{array}{l}4.5 \\
{[1.5 ; 8.5]}\end{array}$ & $\begin{array}{l}19.5 \\
{[18.2 ; 20.8]}\end{array}$ & $\begin{array}{l}-0.5 \\
{[-0.7 ;-0.4]}\end{array}$ & $\begin{array}{l}0.6 \\
4] \quad[0.4 ; 0.9]\end{array}$ & $\begin{array}{l}10.4 \\
{[7.8 ; 13.1]}\end{array}$ & $\begin{array}{l}16.9 \\
{[15.7 ; 18.3]}\end{array}$ & $\begin{array}{l}0.1 \\
{[0 ; 0.1]}\end{array}$ & $\begin{array}{l}0.3 \\
{[0.2 ; 0.4]}\end{array}$ \\
\hline T. volvocina & - & & - & & - & & - & $\begin{array}{l}3.5 \\
{[3.2 ; 3.7]}\end{array}$ & - & $\begin{array}{l}-0.3 \\
{[-0.3 ;-0.2]}\end{array}$ & 2] -1 & $\begin{array}{l}3.8 \\
{[0.8 ; 5.7]}\end{array}$ & - & $\begin{array}{l}-0.4 \\
{[-0.8 ;-0.2}\end{array}$ & 2] \\
\hline
\end{tabular}

Biomass density of GC and FP are reported as relative mean, with the minimum and maximum values in square brackets. Biomass of faecal pellets refers to undigested algal cells. Number of replicates for each sampling month (3). Not determined (-). 
time (Ostroumov, 2005). For example, CR was 5-30 $\mu \mathrm{l}$ animal ${ }^{-1} \mathrm{~h}^{-1}$ for some rotifers, 4.7-10.2 $\mathrm{L} \mathrm{h}^{-1} \mathrm{~g}^{-1}$ biomass for polichaeta. CR was $0.15-1.1 \mathrm{ml}$ zoids ${ }^{-1} \mathrm{~h}^{-1}$ for the bryozoan Zoobotryon verticillatum (Bullivant, 1968), 2.2 $\mathrm{L} \mathrm{h}^{-1} \mathrm{~g}^{-1}$ dry weight for $P$. fungosa (Ostroumov, 2005), and up to $30 \mathrm{ml}$ ind $^{-1}$ day $^{-1}$ for Plumatella emarginata (Vohmann et al., 2009).

Interaction between aquatic vegetation and water level are factors determining prey abundance, distribution and their accessibility in the Colfiorito Marsh. Suspended solids consist of organic (e.g. phytoplankton and biotic debris) and inorganic material including those of anthropogenic origin (Thomas, 1997). Since urban or grazing discharges are not permissible in the Natural Park of Colfiorito Marsh, the abundant dissolved solids are almost certainly of autochthonous origin. Bacterioplankton was likely found as part of $\mathrm{DOM}$, as the filter used $(0.45 \mu \mathrm{m})$ for the experiment probably could not retain it. Grazing rates of solids highlighted a different metabolism of $P$. geimermassardi throughout the three sampling months. Indeed, bryozoan showed a greater consumption of suspended solids when the vegetative season began, and then highlighted reduced values of CRs in August, relating them to the approaching end of its biological cycle. The amount of organic matter filtered out of water is larger than the one assimilated by a filter-feeder; some of the food particles they ingested were consequently transferred to the bottom of the ecosystem as faecal pellets. Concentration of digested and undigested algal cells in the faecal pellets allowed to better evaluate data of food ingestion by $P$. geimermassardi. Algal species with positive ingestion efficiency were selected from seston and ingested by $P$. geimermassardi polypides. Among algal species those with positive $A$ values (negative efficiency of assimilation) were observed more frequently undigested in faecal pellets, and therefore it can be assumed that they were not assimilated by bryozoans. Algal species with negative $A$ values were less frequently found undigested jointly to those ingested, but as they were not found in faecal pellets allows to deduce that they were assimilated.

A previous study carried out on freshwater Bryozoa species ( $P$. repens, $P$. casmiana, $F$. sultana and $P$. articulata) collected from Lake Trasimeno evidenced that ingested food was mainly constituted by the genera Cymbella, Navicula, Oocystis, Scenedesmus, Rhoicosphenia, Chlamidomonas and Tetraedron (Taticchi, 1989). Although the phytoplankton communities of Lake Trasimeno and Colfiorito Marsh are different, the previous and the present study show fairly similar results. The algal species characterized by gelatinous capsules, thick cell walls or cells provided by spines or protuberances (e.g. R. curvata, A. falcatus, S. ecornis, S. ellipsoideus S. bibraianum, T. obliquus, A. ovalis, G. constrictum and $U . u \ln a$ ) pass through the intestine either alive or just damaged and then are excreted after partial digestion. On the other hand, the very small algal species ingested passively from seston (Ultraplanktonic species in August) and those without cell walls particularly resistant (e.g. C. quadrata, K. obesa, $S$. quadricauda, T. minimum, G. acuminatum) may represent the major diet of $P$. geimermassardi. In previous studies differences in food preference have been reported for several freshwater bryozoan species: $P$. emarginata feeds primarily on large algae ( $>15 \mu \mathrm{m}$ size fraction) (Vohmann et al., 2009), while $P$. fungosa displays significant grazing on bacteria (Richelle et al., 1994). P. geimermassardi showed high efficiencies for ingestion of small-sized algae, although the species was able to feed on different sized algae and even on diatoms larger than $45 \mu \mathrm{m}$ like $A$. ovalis and G. constrictum. This observation permit to presume that diatoms may be the most appetizing food item for freshwater bryozoan species (Taticchi, 1989). Nonetheless A. ovalis and G. constrictum were indigestible species for $P$. geimermassardi with positive $A$-values. Indeed it is probable to find algae in faecal pellets more or less digested related either to bryozoan species and the digestibility of ingested algal species (Taticchi, 1989). Lastly the undigested species subtracted from the phytoplankton community turn back into the environment via faecal pellets. Although the analysis of fecal pellets can be considered a limited value to determine food selection, it is able to provide us useful information on the size of particles ingested by $P$. geimermassardi. Efficiency of $P$. geimermassardi versus different algae sizes changed during summer months and number of species actively selected (highest positive $E$-values) was higher in June (4) and July (5), than in August (3). Among algal species positively selected and assimilated (C. quadrata, $K$. obesa, S. quadricauda, T. minimum and G. acuminatum), only $S$. quadricauda and T. minimum were present in marsh water throughout the three sampling months. Both green algae $C$. quadrata and $K$. obesa were not recorded in July and August, respectively, albeit the diatom G. acuminatum was not present in marsh water in June. Algae species were selected according to the phytoplankton structure; biomass density of Chlorophyceae was higher in June and July than in August, while the concentration of Bacillariophyceae was higher, in August, when compared to June and July.

In conclusion, the present study has shown that $P$. geimermassardi feed on suspended particulate components, and consumes dissolved organic material as well. Moreover, P. geimermassardi showed different size preferences regarding algal species. However, only some of the ingested algae species may be effectively used as nutriment. Furthermore, bryozoans may be able to affect sensibly the phytoplankton community structure. Bryozoans assuming food by filtering food may not only compete with other filterfeeders, but also transfer some of the floating nutrition particles they ingest to the bottom of their environment as faecal pellets. In order to define the strategies of biological diversity preservation, conservation and site management and protection, it is essential to examine and comprehend the ecosystem functioning, focusing on still scarcely studied organisms concerning their interaction with the environment they are living in. In future, broader knowledge concerning feeding preferences of bryozoan species may support predicting their distribution, abundance and safeguard.

Acknowledgments. The authors would like to thank Prof. Tim Wood of Department of Biological Sciences, Wright State University Dayton, $\mathrm{OH}$, for his kindly assistance with the manuscript. The Authors are indebted to the anonymous reviewers for insightful comments and suggestions. We thank Dr A. J. Martin Dörr for improving the use of English in the manuscript. 


\section{References}

APAT-IRSA-CNR. 2003. Metodi analitici per le acque. 2000Parametri chimico-fisici. In: APAT Manuali e linee guida 29/ 2003, Roma, pp. 161-170.

APHA, AWWA, WEF. 1998. Standard methods for the examination of water and wastewater, Washington: APHA, 2-54/2-59 pp.

Best MA, Thorpe JP. 1983. Effects of particle concentration on clearance rate and feeding current velocity in the marine bryozoan Flustrellidra hispida. Mar Biol 77: 85-92.

Best MA, Thorpe JP. 1986. Effects of food particle concentration on feeding current velocity in six species of marine Bryozoa. Mar Biol 93: 225-263.

Bullivant JS. 1968. The rate of feeding of the bryozoan, Zoobotryon verticillatum. NZ J Mar Freshw Res 2: 111-134.

Bushnell JH. 1974. Bryozoa (Ectoprocta). In: Hart CW, Fuller SLH, eds. Pollution ecology of freshwater invertebrates. New York: Academic Press, pp. 157-194.

Eckman JE Okamura B. 1998. A model of particle capture by bryozoans in turbulent flow: significance of colony form. Am Nat 152: 861-880.

Elia AC, Ludovisi A, Taticchi MI. 2001. Study of seasonal variations of Glutathione and detoxificant enzymes in Lophopus crystallinus Pallas (Bryozoa) from Piediluco lake (Umbria, Italy). Ital J Zool 68: 291-297.

Elia AC, Pieroni G, Taticchi MI. 2006. Evaluation of the antioxidant defense of the freshwater bryozoan Cristatella mucedo Cuvier, 1798 (Bryozoa, Phylactolaemata) of Lake Piediluco (Italy). Linzer biol Beitr 38: 39-45.

Elia AC, Galarini R, Dörr AJM, Taticchi MI. 2007. Heavy metal contamination and antioxidant response of a freshwater bryozoan (Lophopus crystallinus Pallas, Phylactolaemata). Ecotox Environ Safe 66: 188-194.

Gauld DT. 1951. The grazing rate of planktonic copepods. J Mar Biol Assoc UK 29: 695-706.

Havens KE, Elia AC, Taticchi MI, Fulton RS. 2009. Zooplanktonphytoplankton relationships in shallow subtropical vs. temperate lakes Apopka (Florida, USA) and Trasimeno (Umbria, Italy). Hydrobiologia 628: 165-175.

Henry V, Bussers JC, Bouquegneau JM, Thome JP. 1989. Heavy metal and PCB contamination of bryozoan colonies in the River Meuse (Belgium). Hydrobiologia 202: 147-152.

Ivlev V. 1961. Experimental ecology of the feeding of fishes, New Haven, Connecticut, USA: Yale University Press.

Jebram D. 1973. Preliminary observations on the influences of food and other factors on the growth of Bryozoa. With the description of a new apparatus for cultivation of sessile plankton feeders. Kiel Meeresforsch 29: 50-57.

Kaminski M. 1991a. Feeding of the freshwater bryozoan Plumatella fungosa (Pall.). 1. Food composition and particle size selection. Acta Hydrobiol 33: 229-239.

Kaminski M. 1991b. Feeding of the freshwater bryozoan Plumatella fungosa (Pallas). 2. Filtration rate, food assimilation, and production of faeces. Acta Hydrobiol 33: 241-251.

Lacourt AW. 1968. A monograph of the freshwater BryozoaPhylactolaemata. Zool Verh Leiden 93: 1-159.

Lisbjerg D, Petersen JK. 2000. Clearance capacity of Electra bellula (Bryozoa) in seagrass meadows of Western Australia. $J$ Exp Mar Biol Ecol 244: 285-296.

Lisbjerg D, Petersen, JK. 2001. Feeding activity, retention efficiency, and effects of temperature and particle concentration on clearance rate in the marine bryozoan Electra crustulenta. Mar Ecol Prog Ser 215: 133-141.
Magazzù G. 1978. Metodi per lo studio del plancton e della produzione primaria, Edizioni GM.

Miyake A, Buonanno F, Saltalamacchia P, Masaki ME, Lio H. 2003. Chemical defence by means of extrusive cortical granules in the heterotrich ciliate Climacostomum virens. Eur J Protistol 39: $25-36$.

Monakov AV. 1998. Feeding of freshwater invertebrates (Pitanie Presnovodnykh Bespozonochnykh), Moscow: Institute of Ecological and Evolutionary Problems, 320 p.

Okamura B. 1987. Particle size and flow velocity induce an inferred switch in bryozoans suspension-feeding behavior. Biol Bull 173: 222-229.

Okamura B, Doolan LA. 1993. Patterns of suspension feeding in the freshwater bryozoan Plumatella repens. Biol Bull 184: 52-56.

Okamura B, Partridge JC. 1999. Suspension feeding adaptations to extreme flow environments in a marine bryozoan. Biol Bull 196: 205-215.

Orsomando E, Tardella FM, Balzelli S. 2004. Flora vascolare e fitocenosi nel Parco Regionale di Colfiorito, Tipografia S, ed. Giuseppe, Pollenza (MC): Orfini numeister.

Ostroumov SA. 2002a. Inhibitory analysis of top-down control: new keys to studying eutrophication, algal blooms, and water selfpurification. Hydrobiologia 469: 117-129.

Ostroumov SA. 2002b. Polyfunctional role of biodiversity in processes leading to water purification: current conceptualizations and concluding remarks. Hydrobiologia 469: 203-204.

Ostroumov SA. 2003a. Studying effects of some surfactants and detergents on filter-feeding bivalves. Hydrobiologia 500: 341-344.

Ostroumov SA. 2003b. Anthropogenic effects on the biota: towards a new system of principles and criteria for analysis of ecological hazards. Riv Bilogia/Biol Forum 96: 159-169.

Ostroumov SA. 2005. Some aspects of water filtering activity of filterfeeders. Hydrobiologia 542: 275-286.

Pratt MC. 2008. Living where the flow is right: How flow affects feeding in bryozoans. Integr Comp Biol 48: 808-822.

Richelle E, Moureau, Z, Van de Vyver G. 1994. Bacterial feeding by the freshwater bryozoan Plumatella fungosa (Pallas, 1768). Hydrobiologia 291: 193-199.

Riisgård HU, Manriquez P. 1997. Filter-feeding in fifteen marine ectoprocts (Bryozoa): particle capture and water pumping. Mar Ecol Prog Ser 154: 223-239.

Rubini A, Pieroni G, Elia AC, Zippilli L, Paolocci F, Taticchi MI. 2011. Novel morphological and genetic tools to discriminate species among the family Plumatellidae (Phylactolaemata, Bryozoa). Hydrobiologia 664: 81-93.

Shunatova NN, Ostrovsky AN. 2001. Individual autozooidal behaviour and feeding in marine bryozoans. Sarsia 86: 113-142.

Taticchi MI. 1989. Some observations on the feeding of freshwater Bryozoa in nature. Riv Idrobiol 28: 219-226.

Taticchi MI, Pieroni G, Gustinelli A, Prearo M. 2005. Aspects of freshwater bryozoan fauna in Italy. Denisia 16, zugleich Kat. OÖ. Landesmus. Neue Ser. 28: 175-188.

Taticchi MI, Elia AC, Battoe L, Havens KE. 2009. First report about freshwater Bryozoa of Florida (Lake Apopka). Ital J Zool 76: 194-200.

Thomas JD. 1997. The role of dissolved organic matter, particularly free amino acids and humic substances, in freshwater ecosystems. Freshw Biol 38: 1-36.

Utermöhl H. 1958. Zur Vervollkommung der quantitativen Phytoplakton Methodik. Int Ver Theor Angew Limnol Mitt 9: 263-272.

Vohmann A, Mutz M, Arndt H, Weitere M. 2009. Grazing impact and phenology of the freshwater sponge Ephydatia muelleri and 
the bryozoans Plumatella emarginata and Fredericella sultana under experimental warming. Freshw Biol 54: 1078-1092.

Winston JE. 1977. Feeding in marine bryozoans. In: Woollaccott RM, Zimmer RL, eds. Biology of bryozoans. New York: Academic Press, 233-271.

Wood TS, Okamura B. 2004. Plumatella geimermassardi, a newly recognized freshwater bryozoan from Britain, Ireland, and continental Europe (Bryozoa: Phylactolaemata). Hydrobiologia 518: $1-7$.
Wood TS, Okamura B. 2005. A new key to the freshwater bryozoans of Britain, Ireland and Continental Europe, with notes on their ecology. In: Sutcliffe DW, ed. Freshwater biological association. Scientific Publication, Vol. 63, p. 112.

Wöss E. 1994. Seasonal fluctuations of bryozoan populations in five water bodies with special emphasis on the life cycle of Plumatella fungosa (Pallas). In: Hayward PJ, Ryland JS, Taylor PD, eds. Biology and palaeobiology of bryozoans. Proc. of the 9th Intern. Bryozoology Conf. Univ. of Wales, Swansea, 1992, pp. 211-214.

Cite this article as: Todini C, Elia AC, Selvaggi R, Scoparo M, Taticchi MI. 2018. Food selection by Plumatella geimermassardi Wood and Okamura, 2004 (Phylactolaemata, Bryozoa). Knowl. Manag. Aquat. Ecosyst., 419, 26. 